\title{
Selection of tubing sizes to prevent erosion for natural gas underground storage well and application
}

\author{
Lingfeng $\mathrm{Li}^{1, \mathrm{a}}$, Changhui $\mathrm{Xu}^{2, \mathrm{~b}^{*}}$,Guofeng $\mathrm{Du}^{3, \mathrm{c}}$, Zizhuo Jiang ${ }^{2, \mathrm{~d}}$, Youliang \\ Wang ${ }^{2, e}$, Dashun Zhu ${ }^{2,}$, Mingzheng $\mathrm{Pu}^{2, \mathrm{~g}}$ \\ ${ }^{1}$ Key Laboratory of Exploration Technologies for Oil and Gas Resources, Ministry of Education, \\ Petroleum Engineering College of Yangtze University, Wuhan, China \\ ${ }^{2}$ Petroleum Engineering College of Yangtze University,Wuhan, China \\ ${ }^{3}$ School of Urban Construction, Yangtze University,Jingzhou, China \\ a lilfeng@yangtzeu.edu.cn, ${ }^{b}$ 97248216@qq.com, ${ }^{c}$ 69606868@qq.com, d675565390@qq.com, \\ e756144822@qq.com, ${ }^{\mathrm{f}} 814975139 @ q q . c o m,{ }^{9}$ 284682880@qq.com
}

\begin{abstract}
Keywords: underground natural gas storage well ; tubing sizes ; Selection ; prevent corrosion and erosion ; application

Abstract. Natural gas is a vital component of the world's supply of energy and a clear energy. Underground natural gas storages are underground facilities for storing natural gas. Optimization on tubing sizes for preventing corrosion in underground natural gas storage well is mainly to prevent erosion. In order to satisfy the need of long term, safe production of underground natural gas storage well, preventing erosion of tubing is important. This paper introduces the methods and procedure of tubing sizes optimization for preventing erosion in underground natural gas storage well. Aiming at the actual situation of $\mathrm{Y}$ underground natural gas storage, this paper optimizes the tubing sizes for preventing erosion. The study above has a good applicability by testing, and can provide reference for erosion preventing of the similar underground natural gas storage wells.
\end{abstract}

\section{Introduction}

Natural gas is a vital component of the world's supply of energy and a clear energy. In recent years, with the rapid development of gas industry, natural gas production engineering have also been more and more important. Underground natural gas storages are underground facilities for storing natural gas. At present, there are three types of underground natural gas storages worldwide, which include depleted oil and gas reservoir gas storages, salt-cave gas storages, and aquifer gas storages. They are distributed mostly in the United States, Canada, the former USSR, and Germany, and 10 30\% of the yearly consumption is supplied by underground natural gas storages[1,2]. According to statistics , about 200 underground natural gas storages had been built worldwide. In recent years, some large underground natural gas storages have been built in China; In addition, a series of larger underground natural gas storages are being planned in northern, northeastern, and southwestern China. Natural gas is generally injected into the natural gas storages in the slack season of gas usage and is produced from storages in the busy season (generally winter) or security period. A high flow rate is adopted for injection or production, and the individual-well productivity should be generally up to $100 \sim 300 \times 10^{4}$ $\mathrm{m}^{3} /$ day.

Underground natural gas storages suffer breathing of higher gas injection and production rates during working and the well-bore bears intermittently the repeated alternating load. Gas storage gas injection and production well completion string should meet the requirements of the working environment of gas storage. The high-pressure gas flow under abnormal conditions should be controlled rapidly, and casing and tubing corrosion by down-hole fluids in the gas injection and production process and the strong injection and production should be considered. In addition, a long service life of completion string is also required. The selection principles of gas storage well completion string include the Following. (1) Meeting the requirement of injection and production scales of gas storage; (2) Suiting the corrosive environment; (3) Ensuring long-term safe operation of injection and production wells; (4) Matching of cost control with technological Measures. 
In the gas storage injection and production well string design, a serious erosion may occur in the tubing of a gas well due to excessive flow velocity, thus leading to premature failure of the tubing. This paper introduces the methods and procedure of tubing sizes optimization for preventing erosion in underground natural gas storage well.

\section{Methods and procedure of tubing sizes optimization for preventing erosion}

The tubing size optimization for gas wells is based on nodal system analysis.

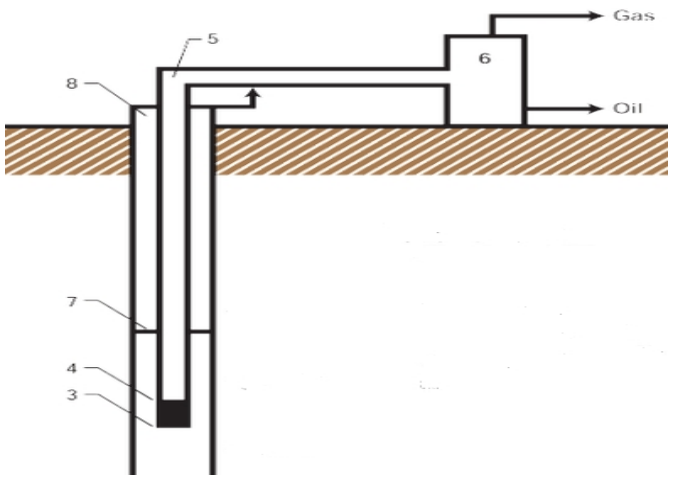

Fig.1: Producing system of natural gas well(1-Formation; 2-Well bottom; 3-Pump intake; 4- Pump discharge; 5-Wellhead; 6-Surface separator; 7-Fluid level; 8-Casing head)

Oil and gas may flow through several components from the reservoir to the surface separator, as shown in Fig.1. From the point of pressure loss, the total pressure loss along the way from the reservoir to the surface separator includes six components of loss.

Methods: The tubing size sensitivity analysis for gas wells is based on nodal system analysis[1,2]. For gas wells, the size range of production casing can be determined on the basis of tubing size sensitivity analysis. The pressure loses flow through the porous medium, completion, tubing string, and flow line are regarded as subsystem A, B , C, and D respectively. The pressure system of the entire production consists of the four pressure subsystems above.
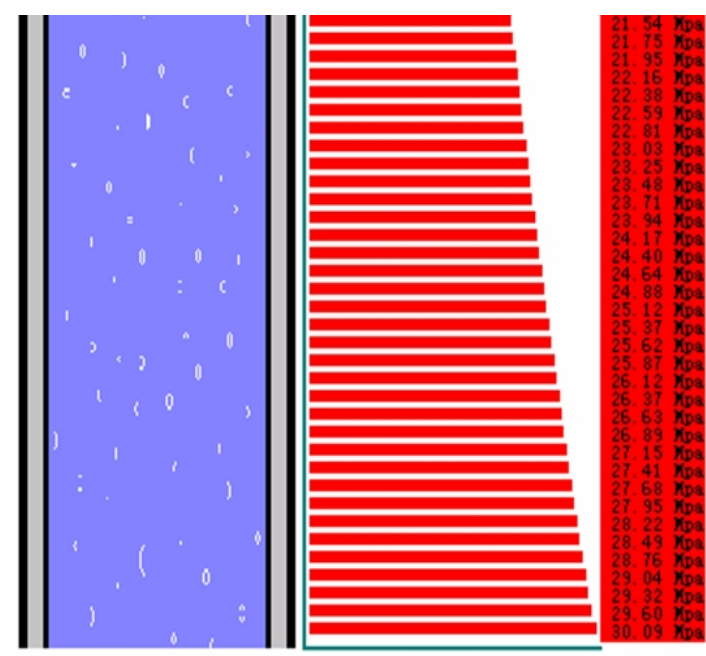

Fig.2: Drawing dynamic curve using nodal analysis

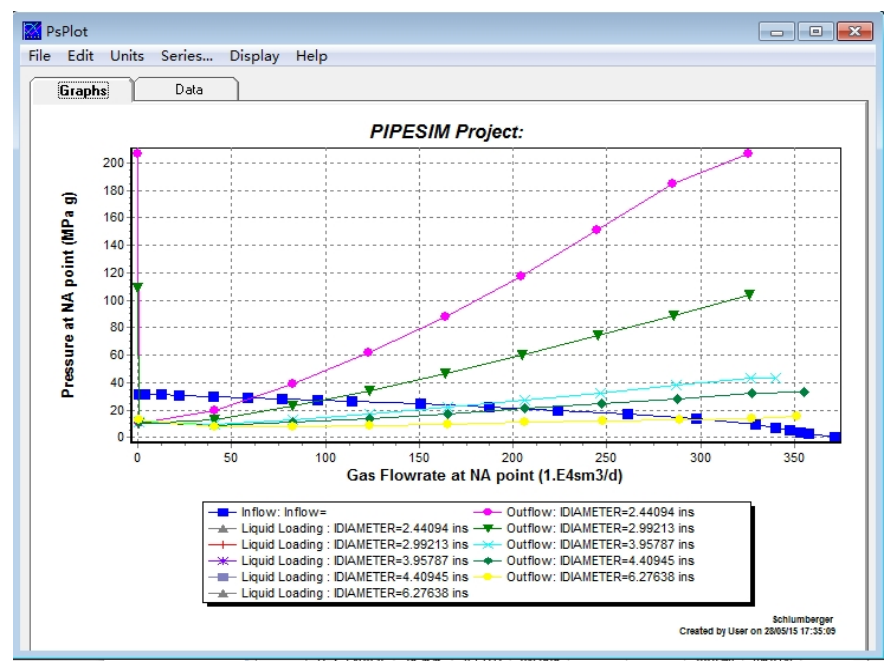

Fig.3: Simulation of pressure of well dynamic curve using nodal analysis

Fig.2 is drawing dynamic curve using nodal analysis. Fig.3 is simulation of pressure of well dynamic curve using nodal analysis. During the flowing production, the flow in tubing can be analyzed by the vertical multiphase flow in pipe. The most significant factors affecting the pressure gradient distribution for vertical multiphase flow are tubing size, flow rate, gas-liquid ratio, viscosity, and water-cut. For a designed well, gas-liquid ratio, viscosity, and water-cut are basically in a range while the flow rate can be controlled and changed. According to the multiphase flow theory, there is an optimum tubing size for which the pressure gradient or pressure loss in the well is minimum at each flow rate. When the flow rate is fixed, tubing size too small will result in high flow velocity that leads to high friction pressure loss; tubing size too large will cause low flow velocity that leads to serious 
slippage effect. Thus only when the proper tubing size is used can the sum of the friction pressure loss and the slippage loss be minimum, and the maximum energy utilization efficiency be achieved.

Since production rate is an important factor of tubing size optimization, and there are different optimum tubing sizes for different flow rate, production rates should be considered the variable in all analyses. During the flow from reservoir to wellhead, production rate is closely related to pressure, hense, pressure is generally regarded as another variable. Usually, the effect of tubing size is analyzed according to pressure-rate ( $\mathrm{p}-\mathrm{Q})$ coordinate plot, and nodal analysis is applied to determine optimum tubing size.

Procedure: Optimization on tubing sizes for preventing corrosion in gas well is mainly to prevent erosion. First of all, apply the nodal system analysis to the optimum tubing size determination by the oil production optimization, and select the basic production casing size. Then consider the requirements of tubing sizes for preventing erosion in gas well, and determine the optimal tubing sizes for preventing corrosion in gas wells.

A serious erosion may occur in the tubing of a gas well due to excessive flow velocity, thus leading to premature failure of the tubing. The Beggs formula is generally used for calculation.

1) Beggs erosion velocity formula, as shown in Equation (1) [3,4]:

$$
V_{e}=\frac{C}{\sqrt{\rho_{g}}}
$$

where: $\mathrm{Ve}=$ erosion flow velocity of erosion, $\mathrm{m} / \mathrm{s} ; \mathrm{C}=$ empirical constant (Corrosion rate can be controlled if flow velocity is lower than the critical flow velocity.); $\rho_{g}=$ gas density, $\mathrm{kg} / \mathrm{m}^{3}$.

2) Anti-erosion production rate formula, as shown in Equation (2)[5,6]:

$$
q_{\mathrm{max}}=55.164 \times 10^{4} \mathrm{~A}\left(\frac{p}{Z T \gamma_{g}}\right)^{0.5}
$$

where: $q_{\max }=$ limiting anti-erosion production rate, $10^{4} \mathrm{~m}^{3} / \mathrm{d} ; \mathrm{A}=$ internal cross-sectional area, $\mathrm{m}^{2}$; $\mathrm{p}=$ mean pressure in tubing, $\mathrm{MPa} ; \mathrm{T}=$ mean temperature in tubing, $\mathrm{K} ; \mathrm{Z}=$ gas deviation factor under bottom-hole condition, dimensionless; $\gamma_{g}=$ relative density of gas. The minimum anti-erosion tubing sizes can be calculated using Equation (2) under different flowing bottom-hole pressures and gas production rates as listed in Table 1.

Table 1: Minimum Anti-Erosion Tubing Sizes
\begin{tabular}{|c|l|l|l|l|l|}
\hline \multirow{2}{*}{$\begin{array}{c}\text { Flowing Bottom-hole } \\
\text { Pressure (MPa) }\end{array}$} & \multicolumn{4}{|c|}{ Daily Gas Production Rate $\left(10^{4} \mathrm{~m}^{3} / \mathrm{d}\right)$} \\
\cline { 2 - 6 } & 200 & 300 & 400 & 500 & 600 \\
\hline 30 & 97.46 & 119.4 & 137.9 & 154.2 & 168.9 \\
\hline 40 & 91.52 & 112.2 & 129.6 & 145 & 158.8 \\
\hline 50 & 87.83 & 107.7 & 124.4 & 139.2 & 152.5 \\
\hline 60 & 85.33 & 104.6 & 120.9 & 135.2 & 148.2 \\
\hline
\end{tabular}

\section{Application}

In this paper, we take $\mathrm{Y}$ underground natural gas storage as an example for anti-erosion performance analysis of gas tubing. According to API RP 14E standard, the use of basic data to calculate the limiting anti-erosion production rate for different tubing sizes is in Table 2. 
Table 2: limiting anti-erosion production rate for different tubing sizes in $\mathrm{Y}$ gas storage

\begin{tabular}{|c|c|c|c|c|c|}
\hline \multirow{2}{*}{$\begin{array}{l}\text { Well } \\
\text { No. }\end{array}$} & \multirow{2}{*}{$\begin{array}{l}\text { Flowing } \\
\text { Wellhead } \\
\text { Pressure } \\
(\mathrm{MPa})\end{array}$} & \multicolumn{4}{|c|}{$\begin{array}{l}\text { limiting anti-erosion production rate for } \\
\text { different tubing sizes }\left(10^{4} \mathrm{~m}^{3} / \mathrm{d}\right)\end{array}$} \\
\hline & & $62 \mathrm{~mm}$ & $76 \mathrm{~mm}$ & $88.3 \mathrm{~mm}$ & $97.2 \mathrm{~mm}$ \\
\hline \multirow{4}{*}{1} & 15 & 36.72 & 55.02 & 74.98 & 96.09 \\
\hline & 20 & 41.05 & 61.524 & 83.83 & 107.43 \\
\hline & 25 & 47.40 & 71.04 & 96.79 & 124.04 \\
\hline & 30 & 53.0 & 79.42 & 108.22 & 138.69 \\
\hline \multirow{3}{*}{3} & 10 & 31.42 & 49.94 & 68.05 & 87.21 \\
\hline & 15 & 38.48 & 61.16 & 83.34 & 106.81 \\
\hline & 20 & 44.46 & 70.62 & 96.231 & 123.33 \\
\hline \multirow{4}{*}{7} & 10 & 32.01 & 50.88 & 69.33 & 88.85 \\
\hline & 15 & 39.2 & 62.32 & 84.91 & 108.82 \\
\hline & 20 & 45.27 & 71.96 & 98.05 & 125.65 \\
\hline & 25 & 50.61 & 80.45 & 109.62 & 140.48 \\
\hline
\end{tabular}

Considering the requirements of tubing sizes for preventing erosion in underground natural gas storage well, the optimal tubing sizes for preventing corrosion in $\mathrm{Y}$ underground natural gas storage can be determined as list in Table 3.

\begin{tabular}{|c|c|c|c|c|}
\hline $\begin{array}{l}\text { Single well production } \\
\text { allocation }\left(\times 10^{4} \mathrm{~m}^{3} / \mathrm{d}\right)\end{array}$ & $\begin{array}{l}100 \sim \\
140\end{array}$ & $\begin{array}{l}80 \sim \\
100\end{array}$ & $50 \sim 80$ & $<50$ \\
\hline Diameter of tubing ( $\mathrm{mm}$ ) & 97.2 & 88.3 & 76 & 62 \\
\hline
\end{tabular}

We can see from table 3 that calculating according to the wellhead pressure $25 \mathrm{MPa}$, tubing diameter is $62 \mathrm{~mm}$ to avoid gas erosion phenomenon when yield is $50 \times 10^{4} \mathrm{~m}^{3} / \mathrm{d}$ or less. When yield is $50 \times 10^{4} \sim 80 \times 10^{4} \mathrm{~m}^{3} / \mathrm{d}$, tubing diameter is $76 \mathrm{~mm}$. When yield is $80 \times 10^{4} \sim 100 \times 10^{4}$ $\mathrm{m}^{3} / \mathrm{d}$, tubing diameter is $88.3 \mathrm{~mm}$. When yield is $100 \times 10^{4} \sim 140 \times 10^{4} \mathrm{~m}^{3} / \mathrm{d}$, tubing diameter is 97.2 $\mathrm{mm}$.

\section{Summary}

In order to satisfy the need of long term, safe and reasonable production of underground natural gas storage well, preventing erosion of tubing is important. This paper introduces the methods and procedure of tubing sizes optimization for preventing erosion in underground natural gas storage well. Aiming at the actual situation of Y underground natural gas storage, this paper optimizes the tubing sizes for preventing corrosion. The study above has a good applicability by testing, and can provide reference for corrosion preventing of the similar underground natural gas storage wells.

\section{Acknowledgments}

This work was supported by PetroChina Innovation Foundation (NO. 2011D-5006-0605) and National Natural Science Foundation of China(NO. 51378077).

\section{References}

[1] Wan Renpu: Advanced Well Completion Engineering (Gulf Professional Publishing, U.S. 2011).

[2] He Shenghou: Oil and Gas Production Engineer Handbook (Petrochemistry Press, China 2006)(In Chinese).

[3] Wan Renpu,et al.: Oil Production Technology Handbook (Petroleum Industry Press, China 2000) (In Chinese).

[4] Jinzhong Chen, Yang Chuandong, Zhangshou Liang, et al.: Gas production engineering (Petroleum Industry Press, China 2004) (In Chinese).

[5] Yang Chuandong: Gas Production Engineering (Petroleum Industry Press, China 2001)(In Chinese).

[6] Shilun Li: Natural Gas Engineering (Petroleum Industry Press, China 2008) (In Chinese). 